Note

\title{
MULTIOBJECTIVE OPTIMIZATION OF ECONOMIC BALANCES OF SUGARCANE HARVEST BIOMASS
}

\author{
Helenice de Oliveira Florentino ${ }^{1 *}$; Edmundo Vergara Moreno ${ }^{2}$; Maria Márcia Pereira Sartori ${ }^{3}$ \\ ${ }^{1}$ UNESP/IB - Depto. de Bioestatística, C.P. 510 - 18618-000 - Botucatu, SP - Brasil. \\ ${ }_{3}^{2}$ Universidad National de Trujillo - Depto. de Matemática, Av. Juan Pablo II, S/N - Trujillo - Peru. \\ ${ }^{3}$ UNESP/FEB - Depto. de Engenharia de Produção, Av. Eng. Luiz E. C. Coube, 14-01 - 17033-360 - Bauru, SP - \\ Brasil. \\ *Corresponding author <helenice@ibb.unesp.br>
}

\begin{abstract}
The fact that Brazil is the world's largest sugarcane (Saccharum spp.) producer, leads to a great concern about the cropping systems used, since the most common practice involves manual harvesting prior to straw burning. Brazilian authorities approved a law prohibiting the burning practice of crop residues prior to harvest. However mechanized harvest creates the new problem of how to deal with the residues. Many studies have proposed the use of these residues as an energy source. The major difficulty in its use is how to economically transport sugarcane harvested biomass from the farm to a processing center. The aim of this work was to develop a model to optimize plant variety selection, minimize the cost of the residual biomass transfer process, to evaluate the economics of using this material, and to address sucrose production and planting area constraints, considering distances from plot to processing center. For this $0-1$ multiple objective linear programming techniques were used. The results show the viability of the model in selecting varieties, which provide increased profit from residual biomass use.

Key words: mathematical model, residual biomass, sugarcane, 0-1 multiple objective linear programming

\section{OTIMIZAÇÃO MULTIOBJETIVO NO BALANÇO ECONÔMICO DA BIOMASSA DE COLHEITADA CANA-DE-AÇÚCAR}

RESUMO: O Brasil é o maior produtor de cana-de-açúcar (Saccharum spp.) do mundo. Mas, existe uma grande preocupação com o sistema de colheita utilizado nesta cultura, pois é prática comum a colheita manual com a pré-queima do palhiço. Autoridades brasileiras têm aprovado leis proibindo a queimada nos canaviais. Entretanto, a colheita mecanizada com cana crua cria novos problemas com a permanência do resíduo no solo. Assim, muitos estudos têm sido propostos para o uso deste resíduo para geração de energia. A maior dificuldade para o uso desta biomassa está no custo de coletar e transferir o resíduo do campo para o centro de processamento. Para análise da viabilidade deste sistema há a necessidade de um estudo do balanço econômico do processo. O objetivo deste trabalho é desenvolver um modelo matemático que auxilie na escolha das variedades de cana a serem plantadas, de forma a minimizar o custo do processo de transferência da biomassa residual de colheita e avaliar economicamente o uso deste material, colocando restrições sobre a produção de sacarose e limitações da área para plantio e considerando as distâncias entre os talhões e o centro de processamento. Para isto, técnicas de programação linear multiobjetivo 0-1 foram utilizadas. Os resultados da aplicação mostram a viabilidade do uso deste modelo para auxílio na seleção de variedades, otimizando o lucro do uso da biomassa residual de colheita para geração de energia.

Palavras-chave: modelo matemático, biomassa residual, cana-de-açúcar, programação linear multiobjetivo 0-1

\section{INTRODUCTION}

Brazil is the largest sugarcane producer, responsible for $25 \%$ of world's yield, with a turnover of more than $\mathrm{R} \$ 20$ billion a year, and direct employment for more than 3.6 million workers in over 300 industries. It is an important socioeconomic crop pro- viding the raw material for three important agro-industries: sugar, spirits and alcohol CONAB (2007); UNICA (2007).

Sugarcane planting uses several genetically improved varieties. Choosing the right variety is not easy; it depends on fundamental agronomic information, industrial factors, and on the interaction of all 
the biotic, abiotic, administrative and economic factors Ripoli \& Ripoli (2004). Although harvest residues are a current worry, they can be turned into profitable raw material for energy generation in a country that imports $27 \%$ of its energy requirements.

The industry has been encouraged by research development into the viability of using residual biomass within their own production or industrial facilities, thus reducing the environmental impact caused by faulty or the poor disposal or dissemination of agroindustrial residues. Various problems such as economic and production quotas, irrigation and many other decisions, have been solved through optimization studies. Beeharry (2001) developed a study to evaluate residue and energy production from sugarcane biomass, concluding that energy production from sugar-cane, which represents $14 \%$ of total energy consumed, could be increased by $50 \%$ by using stalk ends, leaves and straw in an energy production chain. Ismintarti (1996) developed a linear programming model to optimize the use of available resources at the mill. From its results it was evident that the mill was operating below its maximum capacity, resulting in high losses in net income. Sartori et al. (2001) developed two mathematical models showing the possibility of choosing variety after pre-selection through the quantity of residual biomass from harvest, and energy production from this biomass. This study motivated this work, with the aim of developing an optimization model for final variety selection after the usual pre-selection, based on the reduction of harvest cost and time to increase the energy generation of residual biomass recovery and utilization, and evaluating the influence of volume of the material.

The model corresponds to a $0-1$ integer program, that was solved using techniques of the 0-1 multiple objective integer for linear programming Taha (1975); Zeleny (1982); Mavrotas \& Diakoulak (1998) and Florentino (2005).

\section{MATERIAL AND METHODS}

\section{Cost and economic balance}

The harvest cost includes the cost of residue accumulation, cost of loading and the cost of transport. The economic balance $\left(\mathrm{EB}_{\mathrm{al}}\right)$ is determined by the difference between sale price (SP) of the obtained energy and the transfer cost (TC) of the residual biomass from the planting area to the processing center. The transfer cost (TC) of the biomass is the sum of the residue accumulation $\left(\mathrm{C}_{\mathrm{A}}\right)$, collection $\left(\mathrm{C}_{\mathrm{C}}\right)$ and transport $\left(\mathrm{C}_{\mathrm{T}}\right)$ costs. Thus $\mathrm{TC}=\mathrm{C}_{\mathrm{A}}+\mathrm{C}_{\mathrm{C}}+$ $\mathrm{C}_{\mathrm{T}}$
Therefore of balance is: $\mathrm{EB}_{\mathrm{al}}=\mathrm{SP}-\mathrm{TC}$

Multiobjective 1-0 Integer Linear Programming, which were implemented using MATLAB 6.1.0.450 (R 12) software Matlab (1992) in Pentium IV computers, were used in this study.

\section{Mathematical Model}

The goal is to determine the variety $\mathbf{i}$ to be planted on plot $\mathbf{j}$ of area $\mathbf{B}_{\mathbf{j}}$ at a distance $\mathbf{L}_{\mathbf{j}}$ from the processing center, that would offer the maximum possible value from the economic balance of using biomass residuals, with a sucrose yield equal or superior to the average of the pre-selected varieties. To obtain residue accumulation, collection and transport costs, it is necessary determine machinery usage cost. The cost of machine use for residue accumulation (CF), in US\$ ton ${ }^{-1}$ of straw, was determined using the fuel $\operatorname{cost}\left(\mathrm{C}_{\mathrm{f}}\right)$, US\$ $\mathrm{L}^{-1}$, and consumption $(\mathrm{G}), \mathrm{L}$ ton $^{-1}$, therefore $\mathrm{CF}=\mathrm{C}_{\mathrm{f}} \mathrm{G}$. The cost of machine use for collecting the residual biomass of variety $\mathbf{i}\left(\mathrm{Cm}_{\mathrm{i}}\right)$, in US\$ $\mathrm{m}^{-3}$, is calculated by the cost of truck loading $(\mathrm{Cc})$, US\$ ton $^{-1}$ of straw, and the biomass volume per ton (V) in $\mathrm{m}^{3}$ ton $^{-1}$, for each variety (i), as follows: $\mathrm{Cm}_{\mathrm{i}}=\frac{\mathrm{Cc}}{\mathrm{Vi}}$.

The cost of machinery use for residue transport $\left(\mathrm{CD}_{\mathrm{j}}\right)$ associated to plot $\mathbf{j}$ is the fuel truck consumption (C), in $\mathrm{km} \mathrm{L}^{-1}$, to cover the distance to the processing center $(\mathrm{Lj})$ in kilometers; for this route the fuel cost is (pc) US\$ $\mathrm{L}^{-1}$, therefore $\mathrm{CD}_{\mathrm{j}}=\frac{\mathrm{L}_{\mathrm{j}}}{\mathrm{C}} \mathrm{pc}$.

Considering $X_{\mathrm{ij}}=0$ when a variety is not selected for planting on plot $\mathbf{j}$, and $\mathrm{X}_{\mathrm{ij}}=1$ otherwise, then:

$$
\begin{aligned}
& \mathrm{SP}=\sum_{\mathrm{i}=1}^{\mathrm{n}} \sum_{\mathrm{j}=1}^{\mathrm{k}} \mathrm{SP}_{\mathrm{ij}} \mathrm{X}_{\mathrm{ij}} \\
& \mathrm{TC}=\sum_{\mathrm{i}=1}^{\mathrm{n}} \sum_{\mathrm{j}=1}^{\mathrm{k}}\left(\mathrm{C}_{\mathrm{Aij}}+\mathrm{C}_{\mathrm{Tij}}+\mathrm{C}_{\mathrm{Cij}}\right) \mathrm{X}_{\mathrm{ij}}
\end{aligned}
$$

where: $\mathrm{SP}_{\mathrm{ij}}=\mathrm{spb}_{\mathrm{i}} \mathrm{P}_{\mathrm{i}} \cdot \mathrm{B}_{\mathrm{i}} ; \mathrm{spb}_{\mathrm{i}}=$ sole price of the energy, US\$ ton ${ }^{-1} \cdot \mathrm{C}_{\mathrm{Aij}}=\left(\mathrm{P}_{\mathrm{i}} \cdot \mathrm{B}_{\mathrm{j}}\right) \cdot \mathrm{CF} ; \mathrm{C}_{\mathrm{Cij}}=\left(\mathrm{Q}_{\mathrm{i}} \cdot \mathrm{B}_{\mathrm{j}}\right) \cdot \mathrm{Cm}_{\mathrm{i}}$; $\mathrm{C}_{\mathrm{Tij}}=\left[\mathrm{Q}_{\mathrm{i}} \mathrm{B}_{\mathrm{j}} / \mathrm{Vc}\right] \mathrm{CD}_{\mathrm{j}} ; \mathrm{B}_{\mathrm{j}}$ is the planting area in plot $\mathrm{j}$ (ha); $\mathrm{P}_{\mathrm{i}}$ is the production of the biomass of the variety $\mathrm{i}$ (ton ha ${ }^{-1}$ ); $\mathrm{Q}_{\mathrm{i}}$ is the quantity of the biomass of the variety $i\left(\mathrm{~m}^{3} \mathrm{ha}^{-1}\right)$ and $\mathrm{Vc}$ is the volume of load for the truck $\left(\mathrm{m}^{3}\right)$.

Therefore, the use of zero-one integer linear programming techniques is proposed in the following manner: Min TC; $M a x \mathrm{~EB}_{\text {al, }}$, subject to

$$
\begin{aligned}
& \sum_{\mathrm{i}=1}^{\mathrm{n}} \sum_{\mathrm{j}=1}^{\mathrm{k}}\left(\mathrm{B}_{\mathrm{j}} \mathrm{A}_{\mathrm{i}}\right) \mathrm{X}_{\mathrm{ij}} \geq \overline{\mathrm{P}} \\
& \sum_{\substack{i=1 \\
\mathrm{k}}}^{\mathrm{K}} \mathrm{X}_{\mathrm{ij}}=1, \quad \text { for all } \mathrm{j} \\
& \sum_{\mathrm{j}=1}^{\mathrm{k}} \mathrm{X}_{\mathrm{ij}} \leq(\mathrm{k} / \mathrm{m}) \text { for all } \mathrm{i}
\end{aligned}
$$


$\mathrm{X}_{\mathrm{ij}}=0,1 ; \mathrm{i}=1,2, \ldots, \mathrm{n}$ and $\mathrm{j}=1,2, \ldots, \mathrm{k}$

where: $\mathrm{i}=1,2, \ldots, \mathrm{n}$ are the varieties of the system and $\mathrm{n}$ is the number of varieties well adapted to the specific location, $\mathrm{j}=1,2, \ldots, \mathrm{k}$ are the plots for planting; $\overline{\mathrm{P}}$ is the average sucrose production among the varieties ( $\mathrm{t}) ; \mathrm{A}_{\mathrm{i}}$ is the average sucrose production for each variety $i\left(t h^{-1}\right)$ and $m$ is the minimum number of the varieties, determined by the mill.

This model minimizes the residual biomass transfer cost from the planting area to the processing center and maximizes the economic balance of using this material.

Constraint (3) guarantees the demand of sucrose, (4) selects only one variety for each plot (the number of the constraints of (4) is equal the number of the plots), and (5) guarantees the minimum number $(m)$ of varieties to be planted $(m \leq n)$.

\section{Model Application}

Real data from a local mill were taken from ten plots covering a total area of 207.47 hectares and five sugarcane varieties: RB72454, RB806043, RB855536, SP79-1011 and RB855113. The distance from each plot to the processing center varied from 12 to $22 \mathrm{~km}$. Sucrose yield data are shown in Table 1 (Sartori, 2001). The quantity of residual biomass in $\mathrm{m}^{3} \mathrm{ha}^{-1}$ was determined from the difference between the biomass in $\mathrm{kg} \mathrm{ha}^{-1}$ and the residual biomass in $\mathrm{m}^{3} \mathrm{~kg}^{-1}$ (given by the mill), for each variety (Table 1). Collection and loading costs for the residual biomass $(\mathrm{Cm})$ in US $\$ \mathrm{~m}^{-3}$ are shown in Table 1; they were calculated from cost data: for truck loading $(\mathrm{Cc})$, straw value (US\$ ton ${ }^{-1}$ ) three days post raw cane harvest, and biomass volume per ton $\left(\mathrm{V}_{\mathrm{i}}\right)$ in $\mathrm{m}^{3} \operatorname{ton}^{-1}$, for each variety $\mathbf{i}$.

The load volume of the truck was of $54.57 \mathrm{~m}^{3}$, a value chosen not to affect soil compaction (data from the mill). With this information, the proposed model can be solved using the Branch-and-bound algorithm for zero-one multiple objectives linear programming Kiziltan \& Yucaoglu, 1983). The multiobjective Branch- and-bound algorithm is capable of generating all efficient combinations of the $0-1$ variables coupled to the efficient solutions of the model $\left(\mathrm{X}_{\mathrm{ij}}=0\right.$ the variety $\mathrm{i}$ is not selected for planting in plot $\mathrm{j}$ and $\mathrm{X}_{\mathrm{ij}}=1$ the variety $i$ is selected for planting on plot $j$ ). The solution of the model is expressed by the efficient combinations of the binary variables. The identification of these efficient combinations is very helpful in order to study the potential of possible actions before taking a final decision. When multiobjective problems are being considered one of the important issues is the problem of ranking the criteria in terms of their importance and impact on the final result.

\section{RESULTS AND DISCUSSION}

Some points of the efficient frontier are presented in Figure 1. The efficient frontier is the choice of the set containing all pairs (TC, EB) related to the efficient solutions of the model. The point $\Delta$ in Figure 1 was chosen since it is the central point between the minimum and maximum costs. Any other criterion for choosing the solution could be used, depending on the interest of the decision maker.

With this method, a solution to generate a cost of US\$78,321.20 was obtained for the movement of residual biomass, and economic balance of US\$ $60,756.18$ selecting varieties RB855113 for plots 1,3 and 5 (61.82 ha), RB806043 for plots 2,7 and 9 (60.61 ha), SP79-1011 for plot 8 (18.70 ha) and

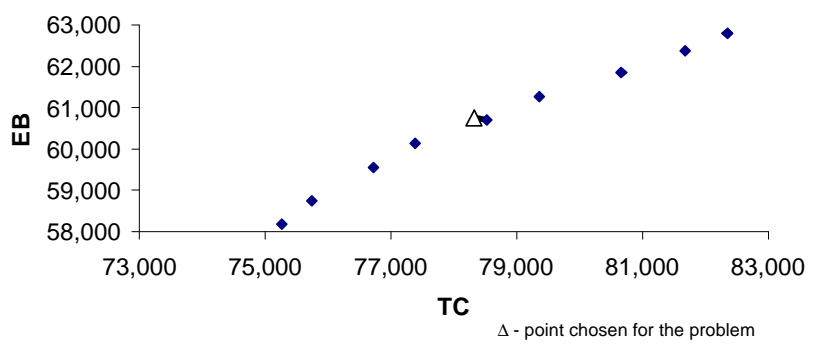

Figure 1 - Some points of the efficient frontiers. $(\mathrm{EB}=$ economic balance; $\mathrm{TC}=$ transfer cost)

Table 1 - Averages of sucrose yields, for four harvests considering variety; quantity of average residual biomass of sugarcane for each variety and Cost of the collection of the residual biomass, also by variety.

\begin{tabular}{lcccc}
\hline Subscript - Variety & Sucrose & Volume & Volume per area & Cost of the collection \\
\hline & $\mathrm{t} \mathrm{ha}^{-1}$ & $\mathrm{~m}^{3} \mathrm{ton}^{-1}$ & $\mathrm{~m}^{3} \mathrm{ha}^{-1}$ & $\mathrm{US} \$ \mathrm{~m}^{-3}$ \\
1 - RB72454 & 15.26 & 34.02 & 807.12 & 0.059 \\
$2-\mathrm{RB} 806043$ & 14.48 & 28.14 & 590.95 & 0.071 \\
$3-\mathrm{RB} 855536$ & 15.23 & 30.42 & 818.3 & 0.066 \\
$4-\mathrm{SP79}-1011$ & 15.80 & 35.64 & 858.56 & 0.056 \\
5 - RB855113 & 17.54 & 32.61 & 958.08 & 0.061 \\
\hline
\end{tabular}

Source Sartori (2001). 
RB855536 for plots 4, 6 and 10 (66.31 ha), producing a total of $3,267.32$ tons of sucrose.

The average collection cost of this biomass is of 465 dollars per hectare (data from the mill), the cost determined in the model was of 377.51 dollars per hectare, below mill average. The model, using zeroone multiple objectives linear programming techniques, permits biomass use optimization by variety selection. In additional, the model can estimate the planting area for each selected variety, total sucrose production, with the cost and economic benefic acceptable and the of harvest residual biomass collection for the selected varieties in the available areas.

\section{ACKNOWLEDGEMENTS}

To PROPE (Pró-Reitoria de Pesquisa da UNESP), FUNDUNESP (Fundação para o Desenvolvimento da UNESP) and FAPESP (Grant No. 04/08993-0 and No. 06/02476-9) for their financial support.

\section{REFERENCES}

BEEHARRY, R.P. Strategies for augmenting sugarcane biomass availability for power production in Mauritius. Biomass \& Bioenergy, v.20, p.421-29, 2001.

COMPANHIA NACIONAL DE ABASTECIMENTO - CONAB. Available at: http://www.conab.gov.br. Accessed 26 Jun. 2007.

FLORENTINO, H.O. Programação linear inteira em problemas de aproveitamento da biomassa residual de colheita da cana-deaçúcar. Botucatu: UNESP/IB, 2005. 64p. (Livre Docência).
ISMINTARTI. Optimization of raw material supply, milling days and milling schedule: application of optimization model for Trangkil Sugar Mill. Majalah-Penelitian-Gula Indonesia, v.32, p.47-59, 1996.

KIZILTAN, G.; YUCAOGLU, E. An algorithm for multiobjective zero-one linear programming. Management Science, v. 29, p.1444-1453, 1983.

MATLAB. High performance numeric computation and visualization software: reference guide. Natick: Mathwork, 1992.

MAVROTAS, G.; DIAKOULAK, D. A branch and bound algorithm for mixed zero-one multiple objective linear programming. European Journal of Operational Research, v.107, p.530$541,1998$.

RIPOLI, T.C.C.; RIPOLI, M.L.C. Biomassa de cana-de-açúcar: colheita, energia e ambiente. Piracicaba: USP/ESALQ, 2004. $302 \mathrm{p}$.

SARTORI, M.M.P.; FLORENTINO, H.O.; BASTA, C.; LEÃO, A.L. Determination of the optimal quantity of crop residues for energy in sugarcane crop management using linear programming in variety selection and planting strategy. Energy, v.26, p.10311040, 2001

SARTORI, M.M.P. Otimização da produção de energia e biomassa do resíduo de colheita em variedades de cana-de-açúcar. Botucatu: UNESP/FCA, 2001. 108p. Tese (Doutorado).

TAHA, H.A. Integer programming: theory, applications and computations. New York: Academic Press, 1975. 380p.

UNIÃO DA AGROINDÚSTRIA CANAVIEIRA DE SÃO PAULO UNICA. Available at: http://www.unica.com.br. Accessed 26 Jun. 2007.

ZELENY, L. Linear multiple criteria of decision making. New York: MacGraw-Hill, 1982. 222p.

Received January 11, 2007

Accepted May 30, 2008 